\title{
New sources of resistance to Septoria tritici blotch in wheat seedlings
}

\author{
María Rosa Simón • Nadia S. Castillo • Cristina A. Cordo
}

Accepted: 25 April 2016/Published online: 8 May 2016

(C) Koninklijke Nederlandse Planteziektenkundige Vereniging 2016

\begin{abstract}
The resistance of a set of Argentine wheat cultivars, differentials, and foreign lines with known genes of resistance to Zymoseptoria tritici was assessed at the seedling stage against a set of molecularly characterized Argentine fungal isolates under three experimental conditions. The experimental design was a split-splitplot with two replications. The environment conditions were the main plots, the fungal isolates were the subplots and the wheat lines with known resistance genes or used as differential lines or the Argentine commercial cultivars were the sub-subplots. Sixteen fungal isolates were inoculated on 23 wheat accessions including 12 foreign lines with known resistance genes, two differential lines, and nine Argentine cultivars that were selected on the basis of
\end{abstract}

María Rosa Simón and Nadia S. Castillo contributed equally.

M. R. Simón $(\bowtie)$

Cerealicultura, Facultad de Ciencias Agrarias y Forestales, Universidad Nacional de La Plata, 60 y 119, CC 31, La Plata 1900, Argentina

e-mail: mrsimon@agro.unlp.edu.ar

N. S. Castillo $(\bowtie)$

IGEVET (Instituto de Genética Veterinaria Dr. Fernando Dulout)CONICET (Consejo Nacional de Investigaciones Científicas y

Técnicas), Facultad de Ciencias Veterinarias, Universidad Nacional de La Plata, calle 60 y 117, CC 31, La Plata 1900, Argentina

e-mail: nadiacastillo22@yahoo.com.ar

C. A. Cordo

CIDEFI (Centro de Investigaciones de Fitopatología)- CIC

(Centro de Investigaciones Científicas de la Provincia de Buenos

Aires), Facultad de Ciencias Agrarias y Forestales, Universidad

Nacional de La Plata, 60 y 119, CC 31, La Plata 1900, Argentina their moderate resistance to natural infection, to identify isolate-specific and partial resistances. The genotypes TE 9111 and Oasis among the foreign lines along with the Argentine cultivars Pro INTA Puntal, Klein Volcán and Buck 75 Aniversario expressed the highest number of specific-resistance interactions. Flame, Tadinia and Kavkaz among the foreign lines showed partial resistances to a higher number of fungal isolates; a comparable resistance pattern was also obtained in the Argentine cultivars Klein Sagitario, Klein Dragón, Don Ernesto and Buck Arriero. Our study demonstrated that the presence of resistance genes in several foreign lines against Septoria tritici blotch is effective against some of the Argentine fungal isolates. In addition, the Argentinean wheat cultivars that showed isolate-specific and nonspecific resistances probably carry novel resistance genes against the pathogen.

Keywords Isolate-specific and nonspecific resistance . Mycosphaerella graminicola $\cdot$ Triticum aestivum

\section{Introduction}

Septoria-tritici blotch (STB) is caused by the fungus Zymoseptoria tritici (Desm.) Quaedvlieg \& Crous (syn. Mycosphaerella graminicola, Septoria tritici). STB is a major foliar disease of wheat worldwide. Therefore, new sources of resistance along with a more extensive knowledge concerning the genetics of resistance have become necessary in order to improve the breeding for resistance to this disease (Chartrain et al. 
2004). Z. tritici is a highly genetically diverse pathogen (McDonald et al. 1999); moreover, the fungus may reproduce sexually several times during the growing season of wheat (Kema et al. 1996c). This fecundity increases the risk of adaptation of the pathogen to resistance genes acquired in the host population. The use of fungicides to control STB is expensive as well as not entirely reliable (Chartrain et al. 2004) and may lead to the emergence of fungicide-resistant strains. Although the use of fungicides in some situations is unavoidable, resistant cultivars provide an effective, economical, and environmentally friendly approach to the control of STB epidemics (Eyal 1999). Until the most recent decades, however, little was known about the genetics of resistance to the disease.

Both qualitative and quantitative resistances have now been identified in wheat germplasm. The former typically gives nearly complete resistance that is isolate-specific, and simply inherited, following a gene-for-gene relationship (Brading et al. 2002). In contrast, quantitative or partial resistance is incomplete, polygenic (Jlibene et al. 1994; Simón and Cordo 1998; Zhang et al. 2001), and isolate-nonspecific (Chartrain et al. 2004), and often more durable (Simón and Cordo 1998). Although complete resistance is preferential because of the almost total absence of symptoms in the host, a partial resistance is highly relevant owing to the concomitant durability and expression under a broad spectrum of pathogen isolates. Several authors have reported specific interactions between wheat cultivars and particular isolates of $Z$. tritici (Chartrain et al. 2004; Eriksen et al. 2003; Kema and Van Silfhout 1997) although quantitative resistance has also been found among different genotypes (Brown et al. 2001; Chartrain et al. 2004; Jlibene et al. 1994; Simón et al. 2005). Eighteen major resistance genes have been identified in bread wheat (Triticum aestivum L.): Stb1 to Stb15 (McIntosh et al. 2008), and Stb16 to Stb18 (McIntosh et al. 2012). In addition, several quantitative-trait loci for resistance (QTL) were also found (Eriksen et al. 2003; Kelm et al. 2012; Miedaner et al. 2012; Raman et al. 2009; Risser et al. 2011; Simón et al. 2004; Simón et al. 2007).

Extensive variations in the virulence of the fungus towards different cultivars have been detected during pathogenesis at the seedling stage (Arraiano et al. 2001; Chartrain et al. 2004; Eyal et al. 1985; Kema et al. 1996a, b; Simón et al. 2005). In Argentina, breeders have classified most commercially-grown cultivars in the range of moderate resistance to susceptibility, suggesting the presence of quantitative, nonspecific resistance in those cultivars, although isolate-specific quantitative resistance may also be present in some cultivars. Although specific interactions between cultivars and isolates have been reported (Perelló et al. 1991; Simón et al. 2005), an accurate characterization of the resistance levels of new cultivars against different fungal isolates is scarce, as the type of resistance has not been investigated previously. Novel sources of resistance and knowledge about the effectiveness of a given resistance against isolates molecularly different are substantially necessary to provide the genetic materials required for improvement of the resistance against STB. In addition, the behavior of germplasm with resistance against the STBs caused by Argentine isolates is still unknown. This knowledge along with the behavior of local cultivars is essential for the planning of crosses with complementary resistances.

The aim of this study was therefore to identify STB resistance at the seedling stage in a set of Argentine wheat cultivars and to compare those characteristics to the properties of foreign wheat lines with known genes and differential lines against 16 molecularly characterized isolates of the pathogen $Z$. tritici.

\section{Materials and methods}

Wheat genotypes and design of experiments

Disease assays were conducted under three different environments on plants grown in the field, in pots outdoors at different locations, and in pots in a growth chamber through use of a split-split-plot design with two replications. The field experiment was performed at the Estación Experimental J. Hirschhorn, Los Hornos, Argentina ( $E E$ environment). Experiments on plants grown in pots placed outdoors ( $F A$ environment) or in growth chamber ( $G W$ environment) were conducted at the Facultad de Ciencias Agrarias y Forestales, La Plata. The environments were the main plots, the isolates the subplots, and the genotypes (i.e., the lines and cultivars) the sub subplots. Sixteen isolates were inoculated on 23 accessions (12 genotypes with known genes, two differential genotypes, and nine Argentine cultivars; Table 1). The set of Argentine cultivars was selected because they had been found to have acceptable resistance levels against natural infections of the pathogen. Most of the foreign genotypes were chosen because they carried known resistance genes and two of them because 
Table 1 Lines and cultivars of Triticum aestivum tested with 16 isolates of Zymoseptoria tritici in two environments

\begin{tabular}{|c|c|c|}
\hline Line/ Cultivar & Origin & Resistance genes mapped or reason for selection for this study \\
\hline Flame & United Kingdom & Stb6 \\
\hline Israel 493 & Israel & Stb3 and Stb6 \\
\hline Kavkaz -K4500 L.6 A.4 & Kenya & Stb6, Stb7, Stb10 and Stb12 \\
\hline Oasis & Russia & Stb1 \\
\hline Tadinia & UnitedStates & Stb4, Stb6 \\
\hline TE 9111 & Portugal & $S t b 6, S t b 7$ and $S t b 11$ \\
\hline Tonic & UnitedKingdom & Stb9 \\
\hline Veranópolis & Brazil & Stb2, Stb6 and $S t b 11$ \\
\hline W7984 SyntheticHexaploid & UnitedStates & Stb5 and $S t b 8$ \\
\hline Capelle & France & differential line \\
\hline IAS 20 & Brazil & differential line \\
\hline Saratovskaja 19 & Russia & susceptible control \\
\hline Janetzkis Probat & Austria & susceptible control \\
\hline Buck 75 Aniversario & Argentina & Argentine cultivar \\
\hline Buck Arriero & Argentina & Argentine cultivar \\
\hline Buck Ranquel & Argentina & Argentine cultivar \\
\hline Don Ernesto INTA & Argentina & Argentine cultivar \\
\hline Klein Dragón & Argentina & Argentine cultivar \\
\hline Klein Sagitario & Argentina & Argentine cultivar \\
\hline Klein Volcán & Argentina & Argentine cultivar \\
\hline Klein Zorro & Argentina & Argentine cultivar \\
\hline Pro INTA Puntal & Argentina & Argentine cultivar \\
\hline
\end{tabular}

they were differentials against different isolates of $Z$. tritici. Saratovskaja 19 and Janetzkis Probat were included as susceptible controls because they had proved to be sensitive to certain fungal isolates in Argentina in natural infections (Simón, M. R., unpublished data). Ten seeds per genotype were sown in each row in the field or into 10-L pots outside or in 1- L pots in the growth chamber. The plants in the pot and growth chamber experiments were watered regularly (every $2-3$ days) and provided at sowing with $50 \mathrm{~kg} \cdot \mathrm{ha}^{-1} \mathrm{~N}$ as urea and $50 \mathrm{~kg} \cdot \mathrm{ha}^{-1}$ of ammonium diphosphate, then at tillering with $50 \mathrm{~kg} \cdot \mathrm{ha}^{-1}$ as urea.

\section{Zymoseptoria tritici isolates and inoculation}

Sixteen monosporic isolates of the pathogen Z. tritici were chosen based on differences in their molecular characteristics determined by ten ISSR molecular markers (Castillo et al. 2010). In this study, the dendrogram generated by the similarity matrix based on Dice's coefficient and the unweight-group method with arithmetic-mean (UPGMA) clustering algorithm showed that at the 0.20 similarity level, 13 distinct clusters were detected (Table 2). We selected the following isolates belonging to different clusters from the different locations: FALP $00105(1 \mathrm{~N}), 00205(2 \mathrm{~N})$, $01405(14 \mathrm{~N}), 02005(20 \mathrm{~N}), 02405(24 \mathrm{~N}), 05205$ (52TA), 20107 (201NJ), 20507 (P), 21707 (217NJ), $22607(226 \mathrm{NJ}), 23007$ (230NJ), 24307 (243NJ), 24407 (244NJ), 24707 (247NJ), 24807 (248NJ), and $25405(254 \mathrm{NJ})$. Table 3 lists the codes, names, and origins of Z. tritici isolates used, and all of them were obtained from bread-wheat cultivars growing at different locations (Fig. 1; Castillo et al. 2010): Necochea [N] and Tres Arroyos [TA] (wheat sub region IV, Argentina) or Nueve de Julio [NJ] and Pla [P] (wheat sub region II South, Argentina).

Cluster I was the largest cluster containing 50 isolates. In cluster I, isolates $1 \mathrm{~N}, 2 \mathrm{~N}, 20 \mathrm{~N}$, and $24 \mathrm{~N}$ from Necochea, 52TA from Tres Arroyos, and 226NJ from Nueve de Julio were selected for inoculation in this study. 
Table 2 Cluster analysis and Zymoseptoria tritici isolates belonging to each cluster

\begin{tabular}{|c|c|c|}
\hline Cluster & Isolates & Origin \\
\hline \multirow[t]{4}{*}{ Cluster I } & $\begin{array}{l}\text { FALP00105, FALP00205, FALP00305, FALP02005, } \\
\text { FALP02405, FALP02605, FALP03005, FALP03305, } \\
\text { FALP03505, FALP03805, FALP04305, FALP04405, } \\
\text { FALP04905, FALP05605, FALP07005, FALP07205, } \\
\text { FALP07605, FALP07705, FALP08205, FALP08305, } \\
\text { FALP08705, FALP09505, FALP09705, FALP10205, } \\
\text { FALP10305, FALP10605, FALP12205, FALP13005, } \\
\text { FALP14205, FALP15205, FALP22505, FALP22705, } \\
\text { FALP23905, FALP25305 and FALP29305. }\end{array}$ & Necochea \\
\hline & FALP05005 and FALP0 5205 & Tres Arroyos \\
\hline & $\begin{array}{l}\text { FALP20207, FALP22607, FALP22807, FALP22907, } \\
\text { FALP23207, FALP23607, FALP23707, FALP23807, } \\
\text { FALP24907, FALP25507, FALP26007 and FALP29207 }\end{array}$ & Nueve de Julio \\
\hline & FALP22407 & Pla \\
\hline \multirow[t]{3}{*}{ Cluster II } & FALP07405, FALP08505, FALP13705 and FALP14905 & Necochea \\
\hline & $\begin{array}{l}\text { FALP21507, FALP24707, FALP25007, FALP26507 and } \\
\text { FALP29107 }\end{array}$ & Nueve de Julio \\
\hline & FALP04705 and FALP08905 & Tres Arroyos \\
\hline Cluster III & FALP09805 and FALP10005 & Necochea \\
\hline \multirow[t]{3}{*}{ Cluster IV } & FALP03905 and FALP07505 & Necochea \\
\hline & FALP20507 & Pla \\
\hline & FALP20807 & Nueve de Julio \\
\hline Cluster V & FALP7805 and FALP12005 & Necochea \\
\hline Cluster VI & FALP24807 & Nueve de Julio \\
\hline \multirow[t]{2}{*}{ Cluster VII } & FALP08105 and FALP10505 & Necochea \\
\hline & FALP24407 & Nueve de Julio \\
\hline \multirow[t]{2}{*}{ Cluster VIII } & FALP20107 and FALP21407 & Nueve de Julio \\
\hline & FALP20307 & Pla \\
\hline \multirow[t]{2}{*}{ Cluster IX } & FALP09305 & Tres Arroyos \\
\hline & FALP25405 & Nueve de Julio \\
\hline Cluster X & FALP21707 & Nueve de Julio \\
\hline Cluster XI & FALP23007 & Nueve de Julio \\
\hline Cluster XII & FALP07905 & Necochea \\
\hline Cluster XIII & FALP09905 & Necochea \\
\hline
\end{tabular}

One isolate, $247 \mathrm{NJ}$, was selected from total 12 isolates of cluster II. No isolates were selected from clusters III and V because each of these clusters contained only two isolates collected from Necochea, a location already well represented by the isolates of other clusters. Likewise, clusters XII and XIII were excluded since they contained only one isolate each. Among the four isolates of cluster IV, 205P was chosen because Pla was not represented in the set of isolates selected. Clusters VI, $\mathrm{X}$, and XI, containing a single isolate each from Nueve de Julio, were all selected for inoculation. Of clusters VII and VIII containing three isolates each from Nueve de Julio, we selected one isolate from each: $244 \mathrm{NJ}$ and
201NJ, respectively. Similarly, from the Cluster IX comprising only two isolates, we chose $254 \mathrm{NJ}$.

In addition to these 14 isolates selected from the dendrogram, we chose two more isolates, $14 \mathrm{~N}$ and $243 \mathrm{NJ}$, neither of which produced PCR amplicons with any of the primers used and therefore were excluded from the resulting dendrogram. These two isolates likely belong to distinct clusters.

The selected fungal isolates were kept in silica gel and transferred to malt-extract agar for 5-6 days before harvesting spores for inoculations. The inoculum was prepared by suspending conidia scraped from sporulating colonies in deionized water at a concentration of 
Table 3 Codes, names, origins, and years of collection of Zymoseptoria tritici isolates used in this study

\begin{tabular}{|c|c|c|c|c|}
\hline Code of isolate in the text & Name of isolate & Origin & Year of collection & Host \\
\hline $1 \mathrm{~N}$ & FALP00105 & Necochea & 2005 & Bread wheat \\
\hline $2 \mathrm{~N}$ & FALP00205 & Necochea & 2005 & Bread wheat \\
\hline $14 \mathrm{~N}$ & FALP01405 & Necochea & 2005 & Bread wheat \\
\hline $20 \mathrm{~N}$ & FALP02005 & Necochea & 2005 & Bread wheat \\
\hline $24 \mathrm{~N}$ & FALP02405 & Necochea & 2005 & Bread wheat \\
\hline $52 \mathrm{TA}$ & FALP05205 & Tres Arroyos & 2005 & Bread wheat \\
\hline $205 \mathrm{P}$ & FALP20507 & Pla & 2007 & Bread wheat \\
\hline $201 \mathrm{NJ}$ & FALP20107 & Nueve de Julio & 2007 & Bread wheat \\
\hline $217 \mathrm{NJ}$ & FALP21707 & Nueve de Julio & 2007 & Bread wheat \\
\hline $226 \mathrm{NJ}$ & FALP22607 & Nueve de Julio & 2007 & Bread wheat \\
\hline $230 \mathrm{NJ}$ & FALP23007 & Nueve de Julio & 2007 & Bread wheat \\
\hline $243 \mathrm{NJ}$ & FALP24307 & Nueve de Julio & 2007 & Bread wheat \\
\hline $244 \mathrm{NJ}$ & FALP24407 & Nueve de Julio & 2007 & Bread wheat \\
\hline $247 \mathrm{NJ}$ & FALP24707 & Nueve de Julio & 2007 & Bread wheat \\
\hline $248 \mathrm{NJ}$ & FALP24807 & Nueve de Julio & 2007 & Bread wheat \\
\hline $254 \mathrm{NJ}$ & FALP25405 & Nueve de Julio & 2005 & Bread wheat \\
\hline
\end{tabular}

Letters following each code indicate the origin of each isolate: $N$ Necochea, TA Tres Arroyos; $P$ Pla, $N J 9$ de Julio

$5 \times 10^{6}$ spores $\mathrm{ml}^{-1}$ with Tween $20\left(0.5 \mathrm{ml} . \mathrm{l}^{-1}\right)$ added as a surfactant. The wheat plants were inoculated at the two-leaf stage, GS 12 (Zadoks et al. 1974). For the experiment in pots placed in growth chambers or outdoors, the plants were covered with a transparent plastic wrap for $48 \mathrm{~h}$ immediately after inoculation, to maintain

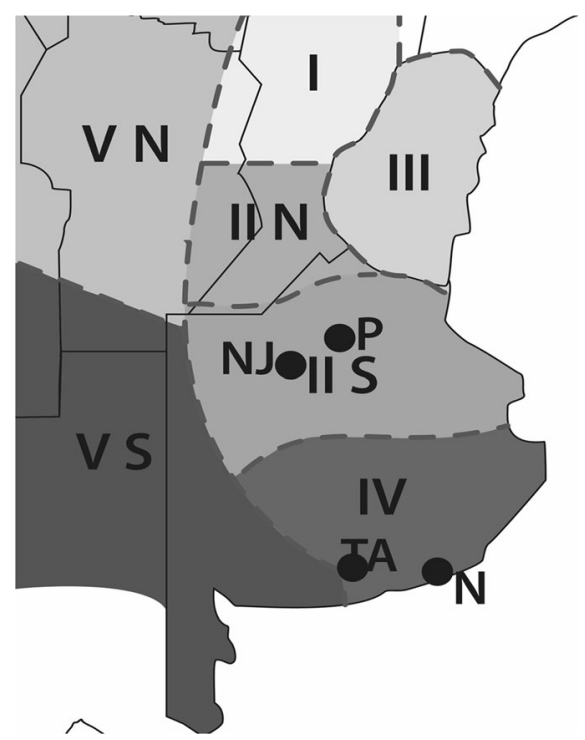

Fig. 1 Map of Argentine Wheat Region showing the locations where the Zymoseptoria tritici isolates were collected within the Province of Buenos Aires. $N$ Necochea, $N J$ Nueve de Julio, $P$ Pla; TA Tres Arroyos a high level of humidity. For the experiment in the field, the plants were kept moist by spraying water for $15 \mathrm{~min}$ with $2 \mathrm{~h}$ interval for 3 days after the inoculations.

Meteorological data were obtained from the Agrometeorological Station located at the Experimental Station, J. Hirschhorn, Los Hornos or at the Astronomical Observatory in La Plata.

Evaluation of disease reaction and data analysis

To estimate seedling resistance, the second leaf of each plant was visually assessed for the percent pycnidial coverage at 28 to 30 days after inoculation in the field or pots outside, whereas pycnidial coverage was estimated at 21-22 days after inoculation in the growth chamber. For the statistical analysis, the Genstat 12th edition 2009, was used. Data normalization was performed by arcsine-square-root transformation (Sokal and Rohlf 2012). Environments, pathogen isolates, host accessions, and the interactions between these factors were fitted as fixed effects; whereas blocks were fitted at random within a split-split-plot design. For testing specific interactions between the genotypes and the fungal isolates, we calculated the least significant differences (LSDs) of the means of genotype by isolate-interaction values (Cherif et al. 2007). 
The lowest mean of transformed disease severity ( $0 \%$ for pycnidial coverage) was used as the resistance control: therefore, the means of interactions that were not greater than the LSD values at a $P \leq 0.01$ level were considered as resistant. In addition, values that were significantly different from the lowest value, but also different from the highest value, indicated a certain level of partial resistance. According to this, only those values up to $35 \%$ in the EE environment, up to $7 \%$ in the FA environment and up to $43 \%$ in the GC environment were considered as carrying partial resistance. To evaluate the general resistance of the wheat genotypes to the isolates tested and the aggressiveness of the latter to the wheat genotypes, the mean disease severities, were calculated by omitting the data for specific interactions (Brown et al. 2001; Chartrain et al. 2004; Ghaneie et al. 2012).

\section{Results}

During the period between the inoculation and the evaluation of disease reaction, in the field experiments (EE environment) the mean temperature was $12{ }^{\circ} \mathrm{C}$ and the mean relative humidity was $77.0 \%$; while in the experiments where plants grew in pots outdoor (FA environment), though the mean temperature was similar, the relative humidity was slightly lower at an average of $74 \%$. For the experiments where plants grew in chambers (GC environment), temperature was set at $20-22{ }^{\circ} \mathrm{C}$ and humidity was at $80-90 \%$. The GC and EE environments evidenced a tendency to be more conducive to the formation of pycnidia. The mean value of the percent pycnidial coverage fluctuated between 0 and $60.8 \%$ for the EE environment, 0 and $17.7 \%$ for the FA environment and 0 and $71 \%$ for the GC environment.

Analysis of variance in disease reactions indicated significant differences between the genotypes and the isolates with respect to the percent pycnidial coverage. All double and triple interactions were also significant (Table 4). Back transformed means are presented in Table 5. Omitting specific-resistance interactions, the isolates $254 \mathrm{NJ}, 248 \mathrm{NJ}, 244 \mathrm{NJ}$ and $20 \mathrm{~N}$ showed the least aggressiveness, whereas $2 \mathrm{~N}, 14 \mathrm{~N}$ and $24 \mathrm{~N}$ were the most aggressive isolates (Table 5).

Among all foreign lines, genotypes IAS 20, TE 9111, Oasis, Israel 493 and Kavkaz, were the most resistant, whereas Saratovskaja 19 and Janetzkis Probat were the most susceptible. Within the Argentine cultivars, Klein
Table 4 ANOVA of percent leaf area covered by pycnidia on the second leaf (GS 12) of 23 lines and wheat cultivars inoculated with 16 isolates of Zymoseptoria tritici, in two environments

\begin{tabular}{llrl}
\hline Source of variation & d.f. & \multicolumn{1}{l}{ m.s. } & $F p r$. \\
\hline Environment & 2 & 16.417 & 0.059 \\
Residual & 2 & 1.022 & \\
Isolate & 15 & 0.525 & $<0.001$ \\
Environment $\times$ Isolate & 15 & 0.037 & $<0.001$ \\
Residual & 45 & 0.006 & \\
Line-Cultivars & 22 & 0.690 & $<0.001$ \\
Environment $\times$ Line-Cultivar & 44 & 0.050 & $<0.001$ \\
Isolate $\times$ Line-Cultivar & 330 & 0.076 & $<0.001$ \\
Environment $\times$ Isolate $\times$ Line-Cultivar & 660 & 0.013 & $<0.001$ \\
Residual & 1056 & 0.006 & \\
\hline
\end{tabular}

Volcán and Buck 75 Aniversario were the most resistant; whereas Klein Zorro and ProINTA Puntal were the most susceptible (Table 5).

Pycnidial coverage values not significantly different from zero in the three environments were considered as indicative of specific resistance, whereas those values that were significantly different from the lowest value but also different from the highest in each environment were considered as indicative of partial non-specific resistance. In addition, we considered as carrying partial resistances, those genotypes that manifested specific resistance in some environments and partial resistance in the others (Table 5).

Both susceptible controls (Janetzkis Probat and Saratovskaya 19) did not exhibit any specific resistance interaction. Furthermore, Janetzkis Probat carried partial resistance to 8 isolates, being susceptible to isolates 14 and 247 in the three environments, whereas Saratovskaya 19 manifested susceptibility to isolates 1 ; 14 and 226 in all the environments, carrying partial resistance to 7 isolates. ProINTA Puntal, Klein Dragón, Klein Sagitario, Klein Zorro, Don Ernesto INTA and Buck Arriero were susceptible to isolate 24 and W 7984 and Buck Ranquel were susceptible to isolate 2 and 52 respectively. Most foreign accessions did not show any susceptibility when the three environments were considered, while the majority of Argentine cultivars were susceptible to isolate 24 (Table 5).

Seventy one fungal-isolate-specific-resistance interactions were detected among a total of 388 combinations ( 23 accessions $\times 16$ isolates). Within the foreign accessions, TE9111 and Oasis showed the highest number of specific interactions (7), followed by Tonic, Veranópolis and Israel 493 (6) and IAS 20 (5). Within 


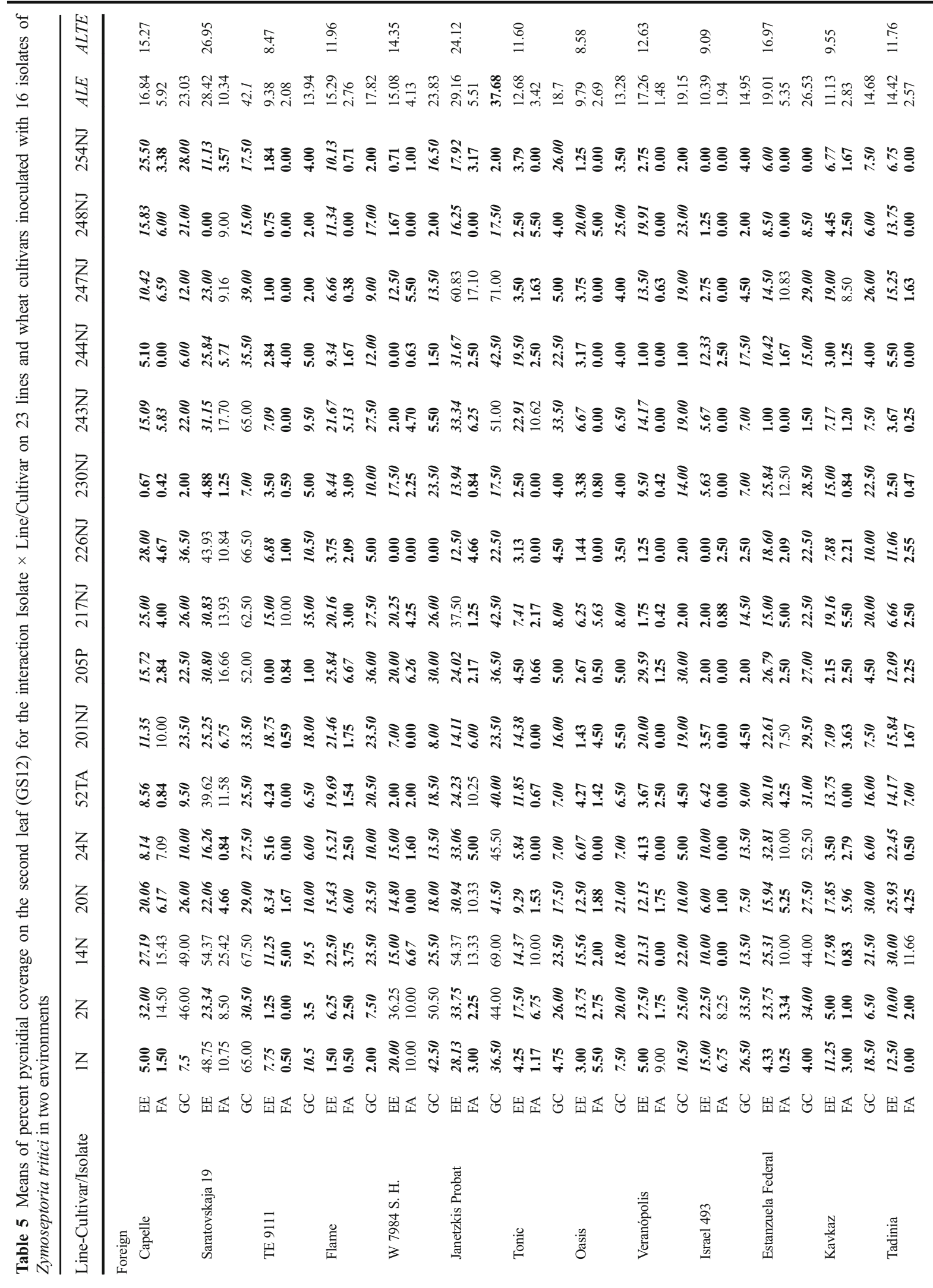




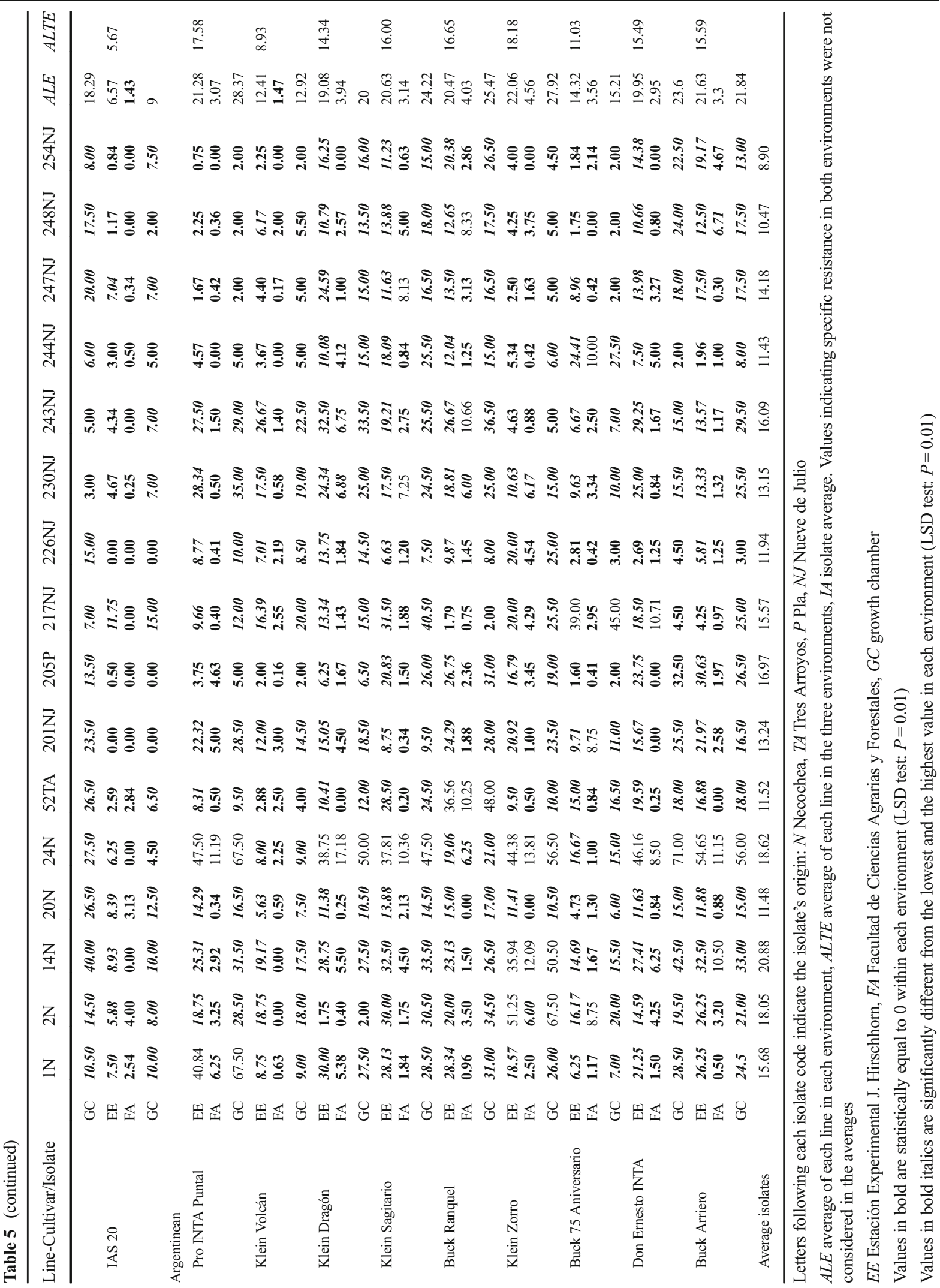


the Argentine cultivars, ProINTA Puntal and Klein Volcán achieved the highest number of isolate-specific resistance (5) followed by Buck 75 Aniversario (4). Flame showed high values of partial resistance against 14 isolates, apart from some specific-resistance interactions. Other foreign accessions with high partialresistance values were Tadinia (13), Kavkaz (13), Capelle (11) and IAS 20 (11) whereas the Argentine cultivars manifesting partial resistances against a higher number of isolates were Klein Sagitario (15) Don Ernesto, Klein Dragón and Buck Arriero (14), Buck Ranquel (12) and Klein Volcán (11). All Argentine cultivars showed partial resistance to more than half of the isolates.

\section{Discussion}

The temperature and humidity values for growing wheat under field conditions or in pots in the present study were within the normal range during growing period when wheat is at the vegetative growth stage in the principal wheat-growing areas in Argentina. Although the temperature was rather low compared to the optimum temperature for the development of $Z$. tritici, it represents naturally occurring conditions at seedling stages of wheat growth in most of the temperate regions of Argentina.

Pycnidial coverage on leaf surface was assessed as a measure of the level of infection and/or resistance. Although other scoring methods have been proposed for assessing the disease severity of STB in wheat (McCartney et al. 2002; Adhikari et al. 2003), the scoring of disease severity based on a visual estimation of the percent leaf area covered by lesions bearing pycnidia still remains as the most common approach (Kema et al. 1996a; Brown et al. 2001; Chartrain et al. 2004). Pycnidial coverage is considered to be more accurate because symptoms cannot be confounded with natural senescence or other pathogens. Notwithstanding, in several experiments host tissue necrosis and pycnidia coverage were found to be highly correlated (Brown et al. 2001; Simón et al. 2005). In our experiments, pycnidial production was more pronounced in the GC and the EE experiments compared to the FF experiment. This difference in pycnidial production could be attributed to the optimum environmental conditions in GC associated with somewhat high level of humidity in the EE environment compared to the FA environment. In field conditions higher density of the canopy might enhance the atmospheric moisture. High humidity is necessary in all stages of the pathogen development during infection processes-i.e., conidial germination, penetration, mycelial invasion within the host tissues, and eventual formation of pycnidia (Browning 1979; Hookes 1957; Shaner and Finney 1976).

This study has identified new sources of resistance in Argentine wheat cultivars at the seedling stage of wheat growth against several molecularly characterized Argentine isolates of $Z$. tritici. This study also provides informative results in determining the behavior of foreign genotypes with known genes against those of same fungal isolates.

The 16 isolates were genetically diverse (Castillo et al. 2010). In addition, those isolates varied in virulence towards the 23 genotypes. The isolates from Nueve de Julio (showing $12.77 \%$ of pycnidial coverage) were on the average less aggressive than the isolates from Necochea (16.94\%). Isolates 244NJ, 226NJ and 205P displayed the highest number of incompatible interactions (with eight occurrences in the three environments) towards the various wheat accessions, thus indicating that these isolates may possess the greatest number of avirulence genes. Although, so far, no avirulence genes have been cloned from $Z$. tritici, all classical genetic approaches indicate that the $Z$. tritici-wheat pathosystem follows the gene-for-gene model (Kema et al. 2000; Brading et al. 2002). We therefore expected that many of the resistant genotypes possessed common or different resistance genes such that their products could recognize the corresponding avirulence gene products. We determined that the genes for resistance in certain of the foreign genotypes were effective against several of the Argentine isolates. In addition, both the foreign and the Argentine cultivars showed specific-resistance interactions in addition to exhibiting partial resistances within the same genotypes in this pathosystem. Similar results had been found by other researchers dealing with different germplasms (Simón et al. 2005; Ghaneie et al. 2012).

Within the foreign lines, Oasis, toghether with TE9111, displayed the highest number of specific interactions with several isolates. Tonic, Veranopolis, Israel 493 (6) and IAS 20 (5) also showed a high number of specific interactions. Gilchrist et al. (1999) found that the high resistance of IAS 20 appeared in different countries through disease testing carried by the International Septoria Observation Nursery 
(ISEPTON). Rosielle and Brown (1979) demonstrated that the resistance in IAS 20 and Veranopolis could be controlled by the same genes because of the similarity regarding to their inheritance patterns, a common ancestor, and comparable levels of disease resistance between these two Brazilian lines. Although our results also indicated a specific resistance against two common isolates (226NJ and 244NJ), IAS 20 and Veranopolis were likewise resistant to certain additional isolates, suggesting that these genotypes could harbor other unknown genes that are effective against Argentine isolates.

Lines Oasis and TE 9111, which carried two known resistance genes, respectively (Stb1 and Stb6 in Oasis; Stb7 and Stb11 in TE 9111) showed a broad spectrum of resistance against several Argentine isolates, indicating that either all fungal isolates carry the avirulence factors recognized by those resistant genes or both cultivars may harbor additional unknown resistance genes. It was also interestingly noticed that the Portuguese breeding line TE 9111 showed specific resistance interactions with several Argentine isolates. This line is also the most resistant to STB described and has long been used as a major source of resistance breeding in Europe (Brown et al. 2001).

The Argentine cultivars manifested different resistance patterns from those of the foreign lines which indicates possible presence of novel resistance genes or different resistance gene combinations, thus making these local cultivars of interest in the effort to broaden the spectrum of resistance to this ubiquitous pathogen. These cultivars are attractive in resistance selection because they showed moderate resistances against natural infections in the field. For this reason, we expect that they would exhibit resistances against several local isolates even though their resistance mechanisms against STB are still unknown.

The present study has characterized the resistance levels of several genotypes of Argentine and foreign wheat cultivars with known resistance genes against a selected set of molecularly characterized Argentine isolates of $Z$. tritici. In addition, the results have enabled a deeper understanding concerning possible novel sources of resistance within existing Argentine cultivars.

Acknowledgments This work was supported by grants provided by ANPCyT (Agencia Nacional de Promoción Científica y Tecnológica) (PICT 08-14489), Universidad Nacional de La Plata (A189 and A 227) and Consejo Nacional de Investigaciones Científicas y Técnicas (CONICET).
We thank Fabiana Consolo and Clara Albani from FIBA (Fundación para Investigaciones Biológicas Aplicadas), Mar del Plata, Buenos Aires Province, Argentina, for their generous cooperation during our molecular testing and Dr. Donald F. Haggerty, a retired career investigator and native English speaker, edited the final version of the manuscript.

\section{References}

Adhikari, T. B., Anderson, J. M., \& Goodwin, S. B. (2003). Identification and molecular mapping of a gene in wheat conferring resistance to Mycosphaerella graminicola. Phytopathology, 93(9), 1158-1164.

Arraiano, L. S., Worland, A. J., Ellerbrook, C., \& Brown, J. K. M. (2001). Chromosomal location of a gene for resistance to Septoria tritici blotch (Mycosphaerella graminicola) in the hexaploid wheat 'Synthetic 6x'. Theoretical and Applied Genetics, 103(5), 758-764.

Brading, P. A., Verstappen, E. C. P., Kema, G. H. J., \& Brown, J. K. M. (2002). A gene for gene relationship between wheat and Mycosphaerella graminicola, the septoria tritici blotch pathogen. Phytopathology, 92, 439-445.

Brown, J. K. M., Kema, G. H. J., Forrer, H. R., Verstappen, E. C. P., Arraiano, L. S., Brading, P. A., Foster, E. M., Fried, P. M., \& Jenny, E. (2001). Resistance of wheat cultivars and breeding lines to septoria tritici blotch caused by isolates of Mycosphaerella graminicola in field trials. Plant Pathology, 50, 325-338.

Browning, J. A. (1979). Genetic protective mechanisms of plant pathogen populations: Their coevolution and use in breeding for resistance. In M. K. Harris (Ed.), Biology and breeding for resistance (pp. 52-57). College Station: Texas A y M University Press. Publ. MP-1451.

Castillo, N., Cordo, C., \& Simón, M. R. (2010). Molecular variability among isolates of Mycosphaerella graminicola, the causal agent of septoria tritici blotch, in Argentina. Phytoparasitica, 38, 379-389.

Chartrain, L., Brading, P. A., Makepeace, J. C., \& Brown, J. K. M. (2004). Sources of resistance to septoria tritici blotch and implications for wheat breeding. Plant Pathology, 53, 454-460.

Cherif, M., Rezgui, S., Devaux, P., \& Harrabi, M. (2007). Interaction between Rhynchosporium secalis and Pyrenophora teres in the field and identification of genotypes with double resistance in a doubled-haploid barley population. Journal of Phytopathology, 155, 90-96.

Eriksen, L., Borum, F., \& Jahoor, A. (2003). Inheritance and localization of resistance to Mycosphaerella graminicola causing Septoria tritici blotch and plant height in the wheat (Triticum aestivum L.) genome with DNA markers. Theoretical and Applied Genetics, 107((3), 515-527.

Eyal, Z. (1999). The septoria tritici and stagonospora nodorum blotch diseases of wheat. European Journal of Plant Pathology, 105, 629-641.

Eyal, Z., Scharen, A., Huffman, M. D., \& Prescott, J. M. (1985). Global insights into virulence frequencies of Mycosphaerella graminicola. Phytopathology, 75, 1456-1462. 
Genstat 12th edition. (2009). Software VSN International.

Ghaneie, A., Mehrabi, R., Safaie, N., Abrinbana, M., Saidi, A., \& Aghaee, M. (2012). Genetic variation for resistance to septoria tritici blotch in Iranian tetraploid wheat landraces. European Journal of Plant Pathology, 132, 191-202.

Gilchrist, L., Gómez, B., González, S., Fuentes, A., Mujeeb-Kazi, W., Pfeiffer, S., Rajaram, R., \& Rodriguez, B. (1999). In M. van Ginkel, A. Mc Nab, \& J. Krupinsky (Eds.), Septoriatriticiresistance sources and breeding progress at CIMMYT, 1970-99. Septoria and Stagonospora Diseases of Cereals. A compilation of global research (pp. 134-139). México: CIMMYT.

Hookes, A. L. (1957). Methods of inoculation and determining varietal reactions in the Septoria disease of oats. Plant Disease Report, 41, 592-597.

Jlibene, M., Gustafson, J. P., \& Rajaram, S. (1994). Inheritance of resistance to Mycosphaerella graminicola in hexaploid wheat. Plant Breeding, 112, 301-310.

Kelm, C., Ghaffary, S. M. T., Bruelheide, H., Röder, M., Miersch, S., Eberhard Webber, W., Kema, G., \& Saal, B. (2012). The genetic architecture of seedling resistance to Septoria tritici blotch in the winter wheat doubled-haploid population Solitär_Mazurka. Molecular Breeding, 29(3), 813-830.

Kema, G. H. J., \& van Silfhout, C. H. (1997). Genetic variation for virulence and resistance in the wheat-Mycosphaerella graminicola pathosystem. III. Comparative seedling and adult plant experiments. Phytopathology, 87, 266-272.

Kema, G. H. J., Annone, J. H., Sayoud, R. S., van Silfhout, C. H., \& van Ginkel, M. (1996a). Genetic variation for virulence and resistance in the wheat-Mycosphaerella graminicola pathosystem. I. Interactions between pathogen isolates and host cultivars. Phytopathology, 86, 200-212.

Kema, G. H. J., Sayoud, R. S., Annone, J. H., \& van Silfhout, C. H. (1996b). Genetic variation for virulence and resistance in the wheat-Mycosphaerella graminicola pathosystem. II. Analysis of interactions between pathogen isolates and host cultivars. Phytopathology, 86, 213-220.

Kema, G. H. J., Verstappen, E. C. P., Todorova, M., \& Waaljwijk, C. (1996c). Succesful crosses and molecular tetrad and progeny analyses demonstrate heterothallism in Mycosphaerella graminicola. Current Genetics, 30, 251-258.

Kema, G. H. J., Verstappen, E. C. P., \& Waalwijk, G. (2000). Avirulence in the wheat septoriatritici leaf blotch fungus Mycosphaerella graminicola is controlled by a single locus. Molecular Plant-Microbe Interactions, 13, 1375-9.

McCartney, C. A., Brule Babel, A. L., \& Lamari, L. (2002). Inheritance of race-specific resistance to Mycosphaerella graminicola in wheat. Phytopathology, 92, 138-144.

McDonald, B. A., Zhan, J., Yarden, O., Hogan, K., Garton, J., \& Pettway, R. E. (1999). The population genetics of Mycosphaerella graminicola and Stagonospora nodorum. In J. A. Lucas, P. Bowyer, \& H. M. Anderson (Eds.), Septoria on cereals: a study of pathosystems (pp. 44-69). Oxon: CAB Publishing.
McIntosh, R. A., Yamazak, Y., Dubcovsky, J., Rogers, J., Morris, C., Somers, D.J., Appels, R. \& Devos, K.M. (2008). Catalogue of gene symbols for wheat. http:/www.grs.nig. ac.jp/wheat/komugi/genes/. Accessed 2015.

McIntosh, R. A., Yamazak, Y., Dubcovsky, J., Rogers, J., Morris, C., Somers, D. J., Appels, R. \& Devos, K. M. 2012. Catalogue of Gene Symbols for Wheat. http:/www.grs.nig. ac.jp/wheat/komugi/genes/. Accesed 2015.

Miedaner, T., Risser, P., Paillard, S., Schnurbusch, T., Keller, B., Harth, L., Holzapfel, H., Korzun, V., Ebmayer, E., \& Friedrich Utz, H. (2012). Broad-spectrum resistance loci for three quantitatively inherited diseases in two winter wheat populations. Molecular Breeding, 29(3), 731-742.

Perelló, A. E., Cordo, C. A., Arriaga, H. O., \& Alippi, H. E. (1991). Variation in virulence of Septoria tritici Rob.ex Desm. Isolates in wheat.Agronomie, 11, 571-579.

Raman, R., Milgate, A. W., Imtiaz, M., \& Martin, P. (2009). Molecular mapping and physical location of major gene conferring seedling resistance to Septoria tritici blotch in wheat. Molecular Breeding, 24(2), 153-164.

Risser, P., Ebmeyer, E., Korzun, V., Hartl, L., \& Miedaner, T. (2011). Quantitative trait loci for adult-plant resistance to Mycosphaerella graminicola in two winter wheat populations. Phytopathology, 101(10), 1209-1216.

Rosielle, A. A., \& Brown, A. G. P. (1979). Inheritance, heritability and breeding behavior of three sources of resistance to Septoria tritici in wheat. Euphytica, 28, 385-392.

Shaner, G., \& Finney, R. E. (1976). Weather and epidemics of septoria leaf blotch of wheat. Phytopathology, 66, 781-785.

Simón, M. R., \& Cordo, C. A. (1998). Diallel analysis of the resistance components to Septoria tritici in Triticum aestivum. Plant Breeding, 117, 123-126.

Simón, M. R., Ayala, F. M., Cordo, C. A., Röder, M. S., \& Börner, A. (2004). Molecular mapping of quantitative trait loci determining resistance to Septoria tritici blotch caused by Mycosphaerella graminicola in wheat. Euphytica, 138(1), 41-48.

Simón, M. R., Perelló, A. E., Cordo, C. A., Larrán, S., van der Putten, P., \& Struik, P. C. (2005). Association between septoria tritici blotch, plant height, and heading date in wheat. Agronomy Journal, 97, 1037-1278.

Simón, M. R., Ayala, F. M., Cordo, C. A., Roder, M. S., \& Börner, A. (2007). The use of wheat/goatgrass introgression lines for the detection of genes determining resistance to septoria tritici blotch (Mycosphaerella graminicola). Euphytica, 154, 249-254.

Sokal, R. R., \& Rohlf, J. F. (2012). Biometry (4th ed.). New York: W. H. Freeman Publisher. 937 pp.

Zadoks, J. C., Chang, T. T., \& Konzak, C. F. (1974). A decimal code for the growth stage of cereals. Weed Research, 14, 415-421.

Zhang, X., Haley, S. D., \& Jin, Y. (2001). Inheritance of septoria tritici blotch resistance in winter wheat. Crop Science, 41, 323-326. 